\title{
A study of plasma proteins in the sol phase of sputum from patients with chronic bronchitis
}

\author{
R A STOCKLEY, ${ }^{1}$ M MISTRY, ${ }^{2}$ A R BRADWELL, ${ }^{2}$ AND D BURNETT ${ }^{2}$
}

From the Department of Medicine, ${ }^{1}$ and the Immunodiagnostic Research Laboratory, Department of Immunology, ${ }^{2}$ University of Birmingham, Edgbaston, Birmingham 15, UK

ABSTRACT We have studied the sputum/serum protein concentration ratios from 23 patients with bronchitis both in the stable clinical state and during acute chest infections. During the stable state there was a significant negative correlation $(2 \mathrm{P}<0.005)$ between the ratio and protein size. 'The ratios of $\operatorname{IgG}, \operatorname{IgA}, \mathrm{C}_{3}$, and alpha $\mathrm{A}_{1}$-antichymotrypsin were significantly displaced from this relation suggesting local production in the lung. IgM was found in all samples and alpha $_{2}$-macroglobulin in $55 \%$ of non-infected samples which may be the result of local production rather than transudation from serum, because of their larger size. During acute chest infections the albumin content of sputum rose from a mean sputum/serum ratio of 0.83 $(\mathrm{SE} \pm 0.08) \times 10^{-2}$ to 13.77 ( $\left.\mathrm{SE} \pm 3.21\right) \times 10^{-2}$ suggesting increased transudation from the blood. In the presence of increased transudation, local production of protein appears to be less significant.

The role of immunoglobulins and proteolytic enzyme inhibitors in protecting the lung from damage is far from clear. In particular there have been conflicting reports concerning the presence of these proteins within the bronchial secretions and whether they are locally produced in the lung.

There are five possible ways in which a protein may enter the bronchial secretions (fig 1). Mechanisms one and two show the production of proteins unique to the bronchial secretions by epithelial cells and submucous glands respectively.

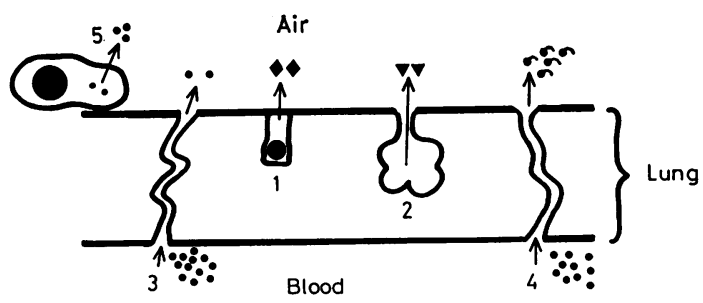

Fig 1 Possible sources of proteins within bronchial secretions. $1=$ Production by epithelial cells; $2=$ Production by submucous glands; $3=$ Passive diffusion from serum; $4=$ Diff usion and alteration within secretions; $5=$ Production by plasma cells or macrophages.
These proteins would be found in the bronchial secretions but not in the serum; an example is the low molecular weight bronchial inhibitor of elastase (Tegner, 1978). Mechnisms three, four, and five relate to proteins also found in serum. These proteins may passively diffuse from serum (3), become structurally altered within the secretion exemplified by the addition of secretory piece to $\operatorname{IgA}(4)$, or be present as the result of passive diffusion together with local production by plasma cells or macrophages (5). Mechanisms 4 and 5 would result in higher concentrations of the protein in the bronchial secretion than could be explained by passive diffusion alone.

Burnett et al (1976) studied the diffusion of plasma proteins into amniotic fluid and showed that the protein concentrations were inversely related to their molecular sizes (fig 2). Protein A has a fluid to serum ratio greater than albumin and thus by convention shows evidence of local production or retention. Proteins $B$ and $C$ have ratios similar to or less than albumin. They are larger molecules, however, and their ratios are higher than would be expected for their size. This also suggests local production or retention.

The present study was designed to clarify the origin of plasma proteins in sputum by measuring their sputum to serum ratios and taking into 


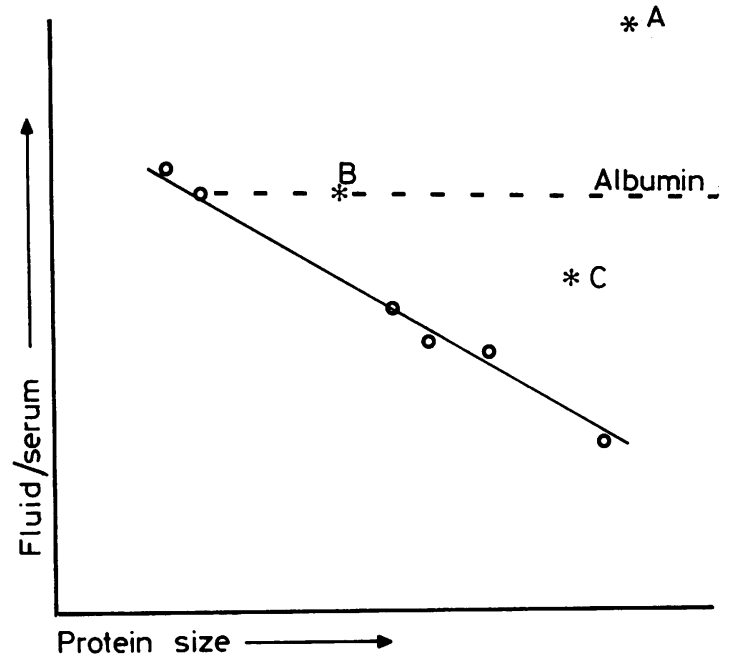

account their molecular sizes. We wished to determine whether any proteins were present in greater concentrations than would be expected by simple diffusion from serum thereby suggesting local retention or production.

\section{Methods}

Twenty-three patients with chronic bronchitis (MRC, 1965) aged 48-75 were studied. Sputum was collected over a four-hour period and a $10 \mathrm{ml}$ sample of blood was taken during this time. The sputum was separated into sol and gel phase (the latter being discarded) by ultracentrifugation $(100000 \mathrm{~g})$ for 90 minutes. The blood was allowed to clot, was centrifuged, and the serum was removed. Samples of serum and sol phase of sputum were stored at $-20^{\circ} \mathrm{C}$ until analysed.

Three of the patients were studied during an acute chest infection, but the remainder were in a stable clinical state (at least two weeks after an infection).

\section{PROTEIN MEASUREMENTS}

Twelve proteins were measured in each sputum and serum sample (albumin, orosomucoid, transferrin, ceruloplasmin, haptoglobin, $\alpha_{1}$ antitrypsin $\left(\alpha_{1}\right.$-AT), $\alpha_{1}$-antichymotrypsin $\left(\alpha_{1}-\mathrm{ACh}\right), \alpha_{2}$-macroglobulin $\left(\alpha_{2}-\mathrm{M}\right), \mathrm{C}_{3}, \operatorname{IgA}$, IgG, and IgM). The immunoglobulins were measured by radial immunodiffusion (Mancini et al, 1965) and the remaining proteins by rocket immunoelectrophoresis (Laurell, 1966). All results were expressed as a percentage of a pooled reference serum (Immunodiagnostic Research Laboratory, Department of Immunology, University of Birmingham). The
Fig 2 Diagrammatic relation between protein size (Stoke's radius, $\mathrm{nm}$ ) and fluid to serum concentration. Proteins present by simple fluid diffusion ( $O$ ) and those actively secreted or locally produced (*).

sputum to serum ratio was then calculated for each protein in each sample. Albumin was taken as the reference protein and the sputum/serum ratio for each protein was divided by the albumin result. This gave a value for albumin of 1 in each sample, and the remaining protein ratios were corrected for albumin.

STOKES RADII

The Stokes radii for most proteins were taken from Burnett et al (1976). Albumin, haptoglobin, $\alpha_{2}-\mathrm{M}$, and IgM were taken from Felgenhauer $(1971,1974)$. The relation between sputum/serum protein ratios and Stokes radii was determined using the least squares method for linear regression $\tilde{x}$ for five proteins. Albumin, orosomucoid, trans- $\frac{0}{7}$ ferrin, ceruloplasmin, and haptoglobin were chosen because they have a range of Stokes $\delta$ radius from $3.45-5.0 \mathrm{~nm}$ and have not been metabolically implicated in lung disease. Their 윽 presence in the sputum was assumed to be the result of passive diffusion alone.

The regression line was used to estimate the $N$ expected sputum/serum ratios of the other proteins for their Stokes radius by interpolation. The expected value was then compared to the ob- $\omega$ served value using the standard error of difference of means.

\section{Results}

All 12 proteins were found in each specimen except $\alpha_{2}$-M which was undetectable $(<200 \mu \mathrm{g} / \mathrm{l}) \stackrel{\Omega}{\Omega}$ in nine of the non-infected patients. Its ratio in $\stackrel{\varnothing}{\Omega}$ these patients was therefore taken as zero.

The sputum/serum ratios of all the proteins 
corrected for albumin are summarised in table 1 for the non-infected patients (divided into smokers and non-smokers) and for the patients with active chest infection. At the bottom of the table is the actual albumin sputum/serum ratio (multiplied by $10^{2}$ for convenience). In the non-infected patients this ranged from 0.45 to 1.37 but was much higher in the three patients with infection as shown in fig $5(7 \cdot 53,15 \cdot 29$, and $18 \cdot 50)$. No significant difference was found between the smokers and nonsmokers for the sputum/serum ratio of any protein.

Mean sputum/serum concentrations of proteins corrected for the albumin result (shown at bottom). Values in parentheses $\pm 1 S E$

\begin{tabular}{|c|c|c|c|c|}
\hline Protein & $\begin{array}{l}\text { Smokers } \\
(n=10)\end{array}$ & $\begin{array}{l}\text { Non- } \\
\text { smokers } \\
(n=10)\end{array}$ & $\begin{array}{l}\text { All } \\
\text { patients } \\
(n=20)\end{array}$ & $\begin{array}{l}\text { Present } \\
\text { infection } \\
(n=3)\end{array}$ \\
\hline Albumin & $1 \cdot 0$ & $1 \cdot 0$ & $1 \cdot 0$ & $1 \cdot 0$ \\
\hline Orosomucoid & $\begin{array}{c}0.60 \\
(0.07)\end{array}$ & $\begin{array}{c}0.78 \\
(0.11)\end{array}$ & $\begin{array}{c}0.69 \\
(0.07)\end{array}$ & $\begin{array}{c}0.67 \\
(0 \cdot 14)\end{array}$ \\
\hline Transferrin & $\begin{array}{c}0.96 \\
(0.09)\end{array}$ & $\begin{array}{c}1.00 \\
(0.08)\end{array}$ & $\begin{array}{c}0.98 \\
(0.06)\end{array}$ & $\begin{array}{c}0.95 \\
(0.08)\end{array}$ \\
\hline Caeruloplasmin & $\begin{array}{c}1.11 \\
(0.20)\end{array}$ & $\begin{array}{c}0.88 \\
(0.12)\end{array}$ & $\begin{array}{c}0.97 \\
(0 \cdot 12)\end{array}$ & $\begin{array}{c}0.16 \\
(0.06)\end{array}$ \\
\hline Haptoglobin & $\begin{array}{c}0.41 \\
(0.06)\end{array}$ & $\begin{array}{l}0.49 \\
(0.09)\end{array}$ & $\begin{array}{l}0.45 \\
(0.08)\end{array}$ & $\begin{array}{l}0.51 \\
(0.34)\end{array}$ \\
\hline$a_{-1}-\mathbf{A T}$ & $\begin{array}{c}1.64 \\
(0.19)\end{array}$ & $\begin{array}{c}1.39 \\
(0.07)\end{array}$ & $\begin{array}{c}1.52 \\
(0 \cdot 10)\end{array}$ & $\begin{array}{c}0.82 \\
(0.05)\end{array}$ \\
\hline$a_{1}-\mathrm{ACh}$ & $\begin{array}{c}6.64 \\
(1.86)\end{array}$ & $\begin{array}{c}3 \cdot 18 \\
(0.40)\end{array}$ & $\begin{array}{c}4.91 \\
(1.01)\end{array}$ & $\begin{array}{c}1.21 \\
(0.23)\end{array}$ \\
\hline$\alpha_{2}-M$ & $\begin{array}{c}0.44 \\
(0.32)\end{array}$ & $\begin{array}{c}0 \cdot 31 \\
(0 \cdot 19)\end{array}$ & $\begin{array}{l}0 \cdot 37 \\
(0 \cdot 18)\end{array}$ & $\begin{array}{l}0.40 \\
(0.09)\end{array}$ \\
\hline IgG & $\begin{array}{c}1.71 \\
(0.25)\end{array}$ & $\begin{array}{l}1.55 \\
(0.24)\end{array}$ & $\begin{array}{c}1.67 \\
(0.17)\end{array}$ & $\begin{array}{c}0 \cdot 70 \\
(0 \cdot 10)\end{array}$ \\
\hline IgA & $\begin{array}{c}17 \cdot 97 \\
(3.65)\end{array}$ & $\begin{array}{c}18.01 \\
(3.54)\end{array}$ & $\begin{array}{l}17.99 \\
(2.46)\end{array}$ & $\begin{array}{c}1.80 \\
(0.34)\end{array}$ \\
\hline IgM & $\begin{array}{c}3.29 \\
(0.65)\end{array}$ & $\begin{array}{r}2.96 \\
(0.97)\end{array}$ & $\begin{array}{c}3.13 \\
(0.57)\end{array}$ & 0.84 \\
\hline $\mathrm{C}_{\mathrm{s}}$ & $\begin{array}{l}1.43 \\
(0.21)\end{array}$ & $\begin{array}{l}1 \cdot 31 \\
(0 \cdot 29)\end{array}$ & $\begin{array}{l}1 \cdot 37 \\
(0 \cdot 18)\end{array}$ & $\begin{array}{c}0 \cdot 60 \\
(0 \cdot 02)\end{array}$ \\
\hline $\begin{array}{l}\text { Albumin } \\
\left(\text { sputum } / \text { serum } \times 10^{2}\right)\end{array}$ & $\begin{array}{c}0.84 \\
(0.12)\end{array}$ & $\begin{array}{c}0.82 \\
(0 \cdot 10)\end{array}$ & $\begin{array}{c}0.83 \\
(0.08)\end{array}$ & $\begin{array}{l}13 \cdot 77 \\
(3 \cdot 21)\end{array}$ \\
\hline
\end{tabular}

\section{RELATION TO STOKES RADIUS}

Non-infected patients

There is a significant inverse relation between the corrected sputum/serum ratios and Stokes radius for the five proteins mentioned earlier. The relation can be expressed as: sputum/serum ratio= 1.55-0.179 $\times$ Stokes radius $(\mathrm{SE} \pm 0.36 ; \mathrm{r}=-0.29$; $\mathrm{t}=2.999 ; 2 \mathrm{p}<0.005$ ) (fig 3).

There are several proteins whose sputum/serum ratios lie outside this relation and some of them are significantly displaced $\left(\alpha_{1}-\mathrm{ACh} \mathrm{P}<0001 ; \mathrm{IgG}\right.$, $P<0.01 ;$ IgA, $P<0.001 ;$ IgM, $P<0.001$; and $C_{3}$, $\mathbf{P}<0.05)$.

\section{Infected patients}

The inverse relation was maintained in the three

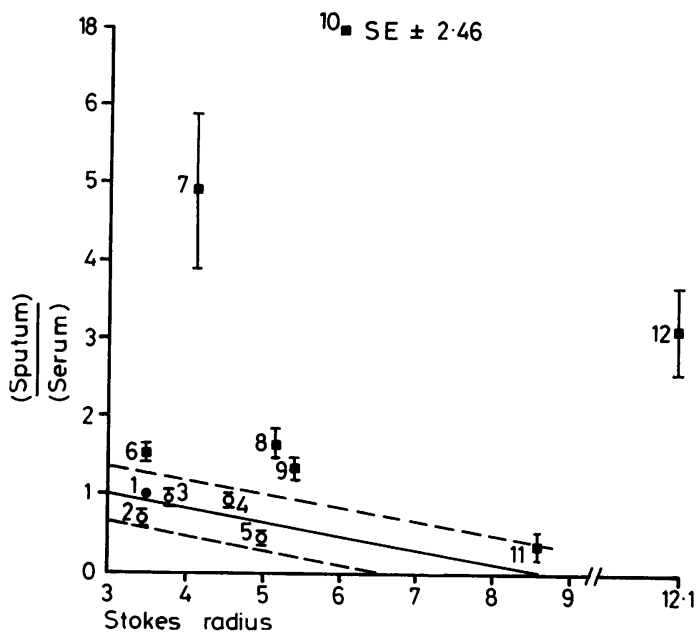

Fig 3 Sputum/serum concentration ratios corrected for albumin plotted against Stokes radius $(\mathrm{nm})$. Regression line $\pm 1 S E$ (-...-) is drawn from albumin (O)-protein 1; orosomucoid-2; transferrin-3; caeruloplasmin-4; haptoglobin -5 . Remaining protein $(\square)$ results are shown $\alpha_{1}$-antitrypsin-6; $\alpha_{1}$-antichymotrypsin-7; $\operatorname{Ig} G-8$; $C_{3}-9 ; \operatorname{Ig} A-10 ; \alpha_{2}$-macroglobulin-11; IgM-12. Bar lines are $\pm 1 S E$.

patients who had active chest infection. Figure 4 shows, however, that most other proteins lie within this relation. Only $\operatorname{IgA}(\mathbf{P}<0.001)$ remained significantly displaced. The relation was: sputum/serum ratio $=2 \cdot 10-0.356 \times$ Stokes radius $(\mathrm{SE} \pm 0.28$; $\mathrm{r}=-0.62 ; \mathrm{t} \pm 2.849 ; 2 \mathrm{p}<0.02$ ).

The intercept is lower than in the non-infected patients. In the presence of inflammation larger proteins would be expected to leak into the secretions raising the intercept. Thus the finding of

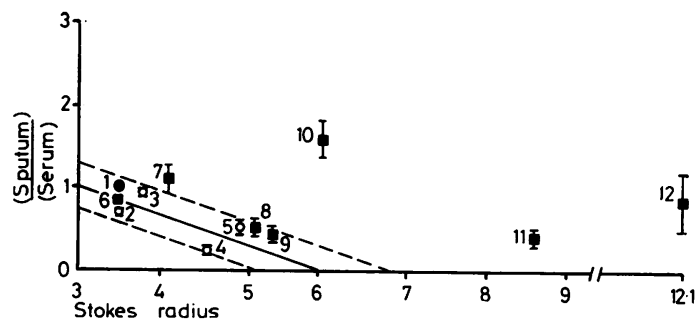

Fig 4 Sputum serum concentration ratios corrected for albumin plotted against Stokes radius in three patients with chest infection. Regression line $\pm 1 S E$ (- . . -) is drawn from albumin (O)-protein 1; orosomucoid-2; transferrin-3; caeruloplasmin-4, haptoglobin -5 . Remaining protein (ם) results are shown $\alpha_{1}$-antitrypsin-6; $\alpha_{1}$-antichymotrypsin -7 ; IgG-8; $C_{3}-9 ;$ IgA-10; $\alpha_{2}$ macroglobulin -11 ; IgM-12. Bar lines are $\pm 1 S E$. 
$\alpha_{2}-\mathrm{M}$ and IgM, which should be absent according to this relation, may merely reflect the small number of infected patients rather than local production.

Despite the fact that IgA is still present in greater concentrations than can be explained by simple diffusion it should be noted that its sputum/ serum ratio corrected for albumin $(1 \cdot 80 \pm 2 \cdot 46)$ was lower than in the non-infected patients $(17.99$ $\pm 2 \cdot 46$ ). Figure 5 shows the sputum/serum ratios of albumin for smokers, non-smokers, and the infected patients, together with the IgA ratio corrected for albumin. The three patients with infection not only had the highest sputum/serum ratios but also the lowest $\operatorname{IgA}$ ratios corrected for albumin (range, non-infected $=4 \cdot 55-38 \cdot 46$; infected values $=1 \cdot 15,1 \cdot 94$, and $2 \cdot 31$ ).
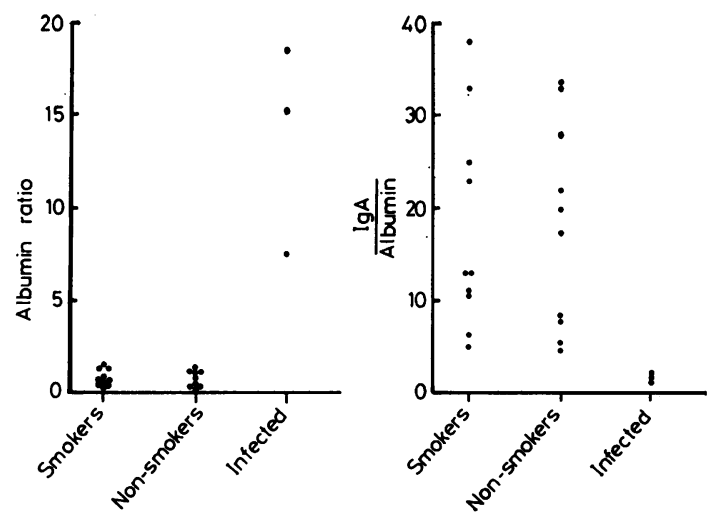

Fig 5 Sputum to serum albumin ratio is given for smokers, non-smokers, and infected patients on left. IgA sputum/serum ratio corrected for albumin is shown in same groups on right.

\section{Discussion}

Bronchial secretions play an important part in protecting the epithelium of the respiratory tract, trapping inhaled particles, and humidifying the air. There are also several soluble proteins within the secretions that may perform a protective function.

Probably most of the soluble protein is derived from serum by passive diffusion, but several workers (Ryley and Brogan, 1973; Soutar, 1977; Warr et al, 1977) have noted that some proteins, particularly $\operatorname{IgA}$, are present in higher quantities suggesting either local production or active transport into the secretions.

The situation with other proteins is less clear. Warr et al (1977) and Reynolds and Newball (1974) found relatively high concentrations of IgG in the secretions of smokers suggesting local pro을 duction whereas Masson et al (1965) and Keimo을 witz (1964) found no evidence of local production? Tegner (1978) found that the proteolytic enzyme inhibitors $\alpha_{1}$-AT, $\alpha_{2}-\mathrm{M}$, and $\alpha_{1}$-ACh were presenes in bronchial secretions, but there was no evidence of local production. Ryley and Brogan (1973) however, presented evidence suggesting tha $\vec{\omega}_{0}$ $\alpha_{1}$-ACh was locally produced in patients with bron chitis, although their methods were less accurate These authors studied sputum, which is a mixturew of bronchial secretions variably contaminated witlos saliva and a small amount of nasopharyngea $i$ secretions, but they emphasised that this would cause dilution of samples rather than alteration of their protein profile. The dilutional effect is overcome by studying protein ratios rather than absolute concentrations, using albumin as a refer? ence. Proteins with secretion/serum ratio less than albumin are said to be present by simple diffusione whereas those whose ratio is greater than albumin are thought to be present partly as a result of local production.

Secretion/serum ratios are also dependent upono protein molecule size (Burnett et al, 1976). This was recognised by Ryley and Brogan (1973). They found the IgG/albumin ratio was the same in sputum as serum, but suggested it should have been lower because IgG is larger than albumin $\overrightarrow{\overrightarrow{0}}$ although they were unable to show this effect clearly.

The relation between sputum/serum concentration ratios and Stokes radius was established from data on five proteins chosen because of their differing sizes and because they have not been metabolically implicated in lung disease. An in-3. verse relation was found suggesting that these five proteins were entering sputum by simple dif $\frac{0}{3}$ fusion. In the non-infected patients four proteins had sputum/serum ratios significantly higher than predicted from this relation: $\operatorname{IgA}, \mathrm{IgG}_{2} \mathrm{C}_{3}$, and $\alpha_{1} \mathrm{ACh}$. Alpha ${ }_{2}-\mathrm{M}$ was found in 11 patients and IgM in all patients and because of their size one would predict that none should be present in sputum unless they were produced locally. How Tิ ever, caution must be expressed concerning $\alpha_{2}-M^{\omega}$ since its displacement is only minimal from an extrapolated line.

The immunoglobulins are probably synthesised by plasma cells within the lung, although $\operatorname{IgA}{ }_{-}^{+}$ containing cells predominate (Martinez-Tello et al, $\overline{0}$ 1968). The bronchial tree also contains many macrophages that are probably the source of $\mathrm{C}_{3} \stackrel{\stackrel{\mathrm{D}}{\mathrm{D}}}{\mathrm{C}}$ production (Ruddy et al, 1972).

The protease inhibitors are of interest because of the association between $\alpha_{1}$-AT deficiency and 
emphysema (Eriksson, 1978). We have found evidence suggesting that $\alpha_{2}-\mathrm{M}$ and $\alpha_{1}-\mathrm{ACh}$ are locally produced or secreted into the bronchial fluids. Lung fibroblasts have been shown to manufacture $\alpha_{2}-\mathrm{M}$ in vitro (Kaighn and Prince, 1971) but information on $\alpha_{1}-\mathrm{ACh}$ is lacking. This enzyme inhibits cationic proteolytic enzymes from granulocytes by the formation of complexes (Ohlsson and Âkesson, 1976) and therefore may play an important part in protecting the lung from damage by these proteases. Whether $\alpha_{1}-\mathrm{ACh}$ is locally produced in the lung is not certain. Burnett (1975) found several samples of amniotic fluid had a higher fluid/serum ratio of $\alpha_{1}$-ACh than would be expected by diffusion. This may be explained by the presence of protein complexes which may alter the antigenic properties of $\alpha_{1}$-ACh resulting in its over-estimation and a broadened precipitation peak on two-dimensional electrophoresis. Ryley and Brogan (1973) measured $\alpha_{1}$-ACh using two-dimensional electrophoresis and commented that the precipitation peak was broadened compared to serum. We measured $\alpha_{1}$-ACh by radial immunodiffusion but have subsequently reviewed our samples using two-dimensional electrophoresis and found similar broadening of the $\alpha_{1}-\mathrm{ACh}$ precipitation peak to a variable degree (fig 6). This may, at least in part, explain the high sputum/ serum ratios in our patients and merits further study.

There are several differences between the results in the non-infected and infected patients. The sputum/serum albumin ratio was much higher in the infected patients. Caution must be expressed in the interpretation of this finding because of small numbers and uncertainty about sample dilution by saliva. It is consistent, however, with increased protein transudation from serum due to bronchial inflammation.

The ratios of $\alpha_{1}-\mathrm{ACh}, \mathrm{IgG}$, and $\mathrm{C}_{3}$ were not different from their predicted values in the infected patients and the IgA (fig 5) and IgM ratios were lower in relation to albumin. These findings are probably the result of increased protein transudation. Local production of protein is likely to be small and highlighted by the relative absence of protein from other sources (serum). When inflammation occurs, protein transudation would increase exceeding local protein production, thus decreasing the relative contribution from local production. The sputum/serum ratios would be reduced to values closer to those expected by diffusion from the serum. This is more likely to account for the low IgA ratios in infection than a reduction in local synthesis as suggested by Soutar (1977). A further study of the relative quantities of

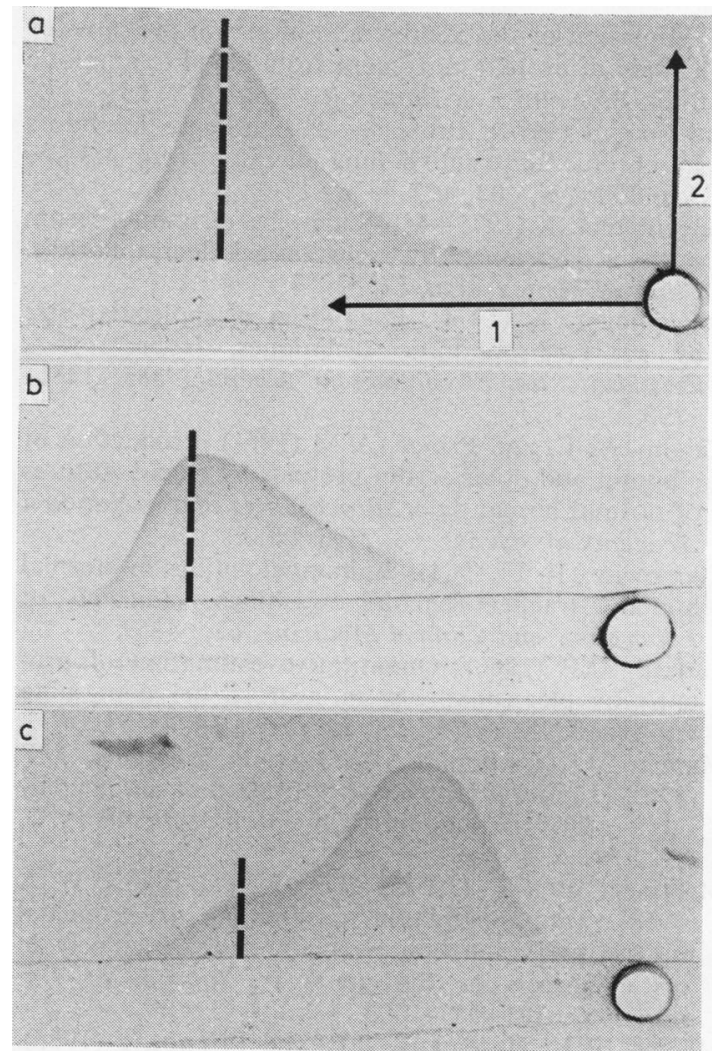

Fig $6 \alpha_{1}$-ACh by two-dimensional electrophoresis. Protein samples placed in well and electrophoresed right to left in plain agar gel $(I)$ and then vertically into gel containing monospecific antibody to $\alpha_{1}-A C h$ (2). Plates a to $c$ are different samples showing progressive broadening of $\alpha_{1}-A C h$ precipitation peak as a result of increasing complex formation (see text). Vertical dotted line indicates mobility of serum $\alpha_{t}-A C h$.

IgA and secretory IgA in patients with and without active chest infection would be necessary to clarify this observation.

This work was supported by grants from the Medical Research Council, Boehringer Ingelheim, and the Rowbotham Bequest. We thank Professors $\mathbf{R}$ Hoffenberg and $J \mathbf{M}$ Bishop for their encouragement and advice and Mrs W Davis for her typing.

\section{References}

Burnett, D (1975). Immunochemical and gel filtration studies of the proteins of serum and amniotic fluid. $\mathrm{PhD}$ thesis, University of Birmingham.

Burnett, D, Wood, S M, and Bradwell, A R (1976). 
Estimation of the Stokes radii of serum proteins for a study of protein movement from blood to amniotic fluid. Biochimica et Biophysica Acta, 427, 231-237.

Eriksson, S (1978). Proteases and protease inhibitors in chronic obstructive lung disease. Acta Medica Scandinavica, 203, 449-455.

Felgenhauer, K (1971). Molecular size of human serum proteins determined by exclusion gel electrophoresis. Clinica Chimica Acta, 32, 53-57.

Felgenhauer, K (1974). Evaluation of molecular size by gel electrophoretic techniques. Hoppe-Seylers Zeitschrift für Physiologische Chemie, 355, 12811290.

Kaighn, M E, and Prince, A M (1971). Production of albumin and other serum proteins by clonal cultures of normal human liver. Proceedings of the National Academy of Science, 68, 2396-2400.

Keimowitz, R I (1964). Immunoglobulins in normal human tracheobronchial washings. Journal of Laboratory and Clinical Medicine, 63, 54-59.

Laurell, C-B (1966). Quantitative estimation of proteins by electrophoresis in agarose gel containing antibodies. Analytical Biochemistry, 15, 45-52.

Mancini, G, Carbonara, A O, and Heremans, J F (1965). Immunochemical quantitation of antigens by single radial immunodiffusion. Immunochemistry, 2, 235-254.

Martinez-Tello, F J, Braun, D G, and Blanc, W A (1968). Immunoglobulin production in bronchial mucosa and bronchial lymph nodes particularly in cystic fibrosis of the pancreas. Journal of Immunology, 101, 989-1003.

Masson, P L, Heremans, J F, and Prignot, J (1965). Studies on the proteins of human bronchial secretions. Biochimica et Biophysica Acta, 111, 466-478.

Medical Research Council Committee on the aetiology of chronic bronchitis (1965). Definition and classifi- $\mathbb{D}$ cation of chronic bronchitis. Lancet, 1, 775-779.

Ohlsson, K, and Åkesson, U (1976). $\alpha_{1}$-anti- के chymotrypsin interaction with cationic proteins from $\overrightarrow{0}$ granulocytes. Clinica Chimica Acta, 73, 285-291.

Reynolds, H Y, and Newball, H H (1974). Analysis $\vec{\omega}$ of proteins and respiratory cells obtained from $\Omega$ human lungs by bronchial lavage. Journal of $\overrightarrow{\times}$ Laboratory and Clinical Medicine, 84, 559-573.

Ruddy, S, Gigli, I, and Austen, K F (1972). The complement system of man. New England Journal of Medicine, 287, 545-549.

Ryley, H C, and Brogan, T D (1973). Quantitative immunoelectrophoretic analysis of the plasma pro- $\triangle$ teins in the sol phase of sputum from patients with chronic bronchitis. Journal of Clinical Pathology, 26, 852-856.

Soutar, C A (1977). Distribution of plasma cells and cells containing immunoglobulins in the respiratory tract in chronic bronchitis. Thorax, 32, 387-396.

Tegner, H (1978). Quantitation of human granulocyte $\vec{\theta}$ protease inhibitors in non-purulent bronchial lavage fluids. Acta Otolaryngologica, 85, 282-289.

Warr, G A, Martin, R R, Sharp, P M, and Rossen, R D (1977). Normal human bronchial immunoglobulins and proteins. American Review of Respiratory Disease, 116, 25-30.

Requests for reprints to: Dr R A Stockley, Department of Medicine, University of Birmingham, Edgbaston, Birmingham 15. 